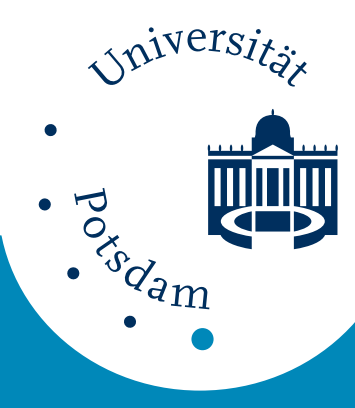

Universität Potsdam

Hans-Jörg Ferenz, Martin G. Peter

The inhibitory effect of sinefungin on juvenile hormone biosynthesis and development in locusts

first published in:

Insect Biochemistry. - 17 (1987), 7, pp. 1119-1122

ISSN 0020-1790

DOI 10.1016/0020-1790(87)90132-6

Postprint published at the Institutional Repository of the

Potsdam University:

In: Postprints der Universität Potsdam :

Mathematisch-Naturwissenschaftliche Reihe ; 76

http://opus.kobv.de/ubp/volltexte/2008/1681/

http://nbn-resolving.de/urn:nbn:de:kobv:517-opus-16811

Postprints der Universität Potsdam

Mathematisch-Naturwissenschaftliche Reihe ; 76 ISSN 1866-8372 


\title{
THE INHIBITORY EFFECT OF SINEFUNGIN ON JUVENILE HORMONE BIOSYNTHESIS AND DEVELOPMENT IN LOCUSTS
}

\author{
Hans-Jörg Ferenz ${ }^{1}$ and Martin G. Peter ${ }^{2}$ \\ 'Fachbereich Biologie, Universität Oldenburg, Postfach 2503, D-2900 Oldenburg, F.R.G., and ${ }^{2}$ Institut \\ für Organische Chemie und Biochemie der Universität, Gerhard-Domagk-Str. 1, D-5300 Bonn, F.R.G.

\begin{abstract}
The antibiotic fungal metabolite sinefungin is a potent inhibitor of S-adenosylmethionineacceptor methyltransferases. Its effect on insect metabolism and especially on corpora allata farnesoic acid methyltransferase, which catalyzes the penultimate step of juvenile hormone biosynthesis, was investigated in Locusta migratoria. Injection of sinefungin results in a delay of imaginal molt and in suppression of ovary development. Isolated corpora allata are unable to synthesize juvenile hormone III in the presence of more than $1.0 \mathrm{mM}$ sinefungin. In a cell-free system containing the S-adenosylmethionine-dependent farnesoic acid methyltransferase from corpora allata sinefungin is a competitive inhibitor of the synthesis of methylfarnesoate with $K_{i}$ of $1 \mu \mathrm{M}$.
\end{abstract}

Key Word Index: Locust, sinefungin, O-methyltransferase, juvenile hormone biosynthesis

\section{INTRODUCTION}

Sinefungin is an antifungal antibiotic isolated from Streptomyces griseolus (Hamill and Hoehn, 1973). It is a structural analog of S-adenosylmethionine (AdoMet) (Fig. 1). Sinefungin has been found to have activity against fungi, viruses and parasites. In various systems it has been shown to be a potent inhibitor of transmethylation reactions. The effect of sinefungin on insects has not been investigated. Of special interest is the farnesoic acid O-methyltransferase (OMT), an enzyme that is involved in the last steps of juvenile hormone $(\mathrm{JH})$ biosynthesis in insect corpora allata (CA) (Weirich, 1985). It is well established that this reaction consists of the transfer of the<smiles>C[Si](C)(C)CCC(N)C(=O)O</smiles>

S-ADENOSYL-METHIONINE

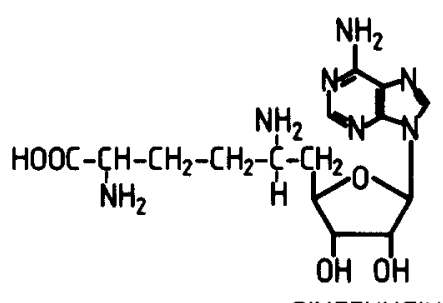

SINEFUNGIN

Fig. 1. Chemical structures of S-adenosylmethionine and sinefungin. methyl group from AdoMet to either farnesoic acid (FA) (Hamnett et al., 1981) or to 10,11-epoxyfarnesoic acid or higher homologues of the latter (Reibstein and Law, 1973; Weirich and Culver, 1979; Peter et al., 1979). Here we describe the effects of sinefungin on Locusta migratoria in vivo and on the inhibition of JH biosynthesis in CA in vitro as well as in CA extracts containing the enzyme OMT.

\section{MATERIAL AND METHODS}

Materials, in vivo experiments and in vitro assays of $\mathrm{CA}$ activity were as described previously (Ferenz et al., 1986; Ferenz and Diehl, 1983).

\section{$O$-methyl transferase assay}

Extracts of 40-50 pairs of CA were prepared as described by Feyereisen et al. (1981). The OMT containing extract was mixed with glycerol (final concentration $15 \%$ ) and stored in several batches frozen at $-70^{\circ} \mathrm{C}$. Aliquots of $10 \mu 1$, containing 1.7 gland pair equivalents (= $=5 \mu \mathrm{g}$ protein) were incubated in $90 \mu 1$ of phosphate buffer $(100 \mathrm{mM}, \mathrm{pH} \mathrm{7.0)}$ containing $1 \mathrm{mM}$ EDTA and $1 \mathrm{mM}$ mercaptoethanol to which $0.4 \mu \mathrm{g}(1.6 \mathrm{nmol}) \mathrm{FA}$ and $0.7 \mu \mathrm{g}$ [methyl$\left.{ }^{14} \mathrm{C}\right] \mathrm{S}$-adenosylmethionine hydrogen sulfate $(1.7 \mathrm{nmol}$, containing $0.1 \mu \mathrm{Ci}$ ) as well as varying amounts of sinefungin were added. The total volume was $100 \mu 1$. After incubation for $30 \mathrm{~min}$ at $30^{\circ} \mathrm{C}$, the mixture was extracted once with $300 \mu \mathrm{l}$ iso-octane containing $14 \mu \mathrm{g}$ methyl farnesoate (MF) and aliquots of the iso-octane phase were removed for counting.

\section{RESULTS}

Effects of sinefungin on larval and adult development Injecting fifth-instar larvae of Locusta with sinefungin resulted in a delay or suppression of metamorphosis depending on the dose applied (data not shown). Dose-dependent reductions in ovary weight, oocyte development and total haemolymph protein were caused by repeated injections of increasing amounts of sinefungin into adult female locusts (Table 1). Often resorption of partly matured oocytes 


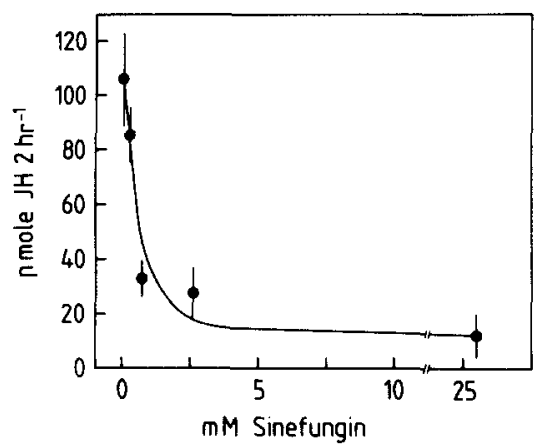

Fig. 2. Effect of sinefungin on JH-biosynthesis in isolated locust $C A$ pairs. Data points are mean values $\pm S E M$ $(n=8)$.

occurred. Attempts to restore the process of sexual maturation in sinefungin-injected female locusts by application of high doses of the $\mathrm{JH}$ analog (RS)-methoprene were not successful. Injection of sinefungin suppressed the strong protein accumulation usually observed in ovariectomized locusts. No vitellogenin or only small amounts were detected in sinefungin animals by immunodiffusion techniques (data not shown).

Inhibition of juvenile hormone biosynthesis in isolated corpora allata

The $\mathrm{JH}$ biosynthesis in isolated CA was measured with a short-term radiochemical assay. This assay utilizes the fact that the labelled methyl group of methyl-methionine is incorporated into the methylester group of $\mathbf{J H}$. Addition of sinefungin resulted in a dose-dependent decrease of incorporation of radioactivity into $\mathrm{JH}$ (Fig. 2). Hormone production fell to background levels at inhibitor concentrations higher than $1 \mathrm{mM}$. Transfer of such CA into fresh medium without sinefungin did not resore the $\mathrm{JH}$ production.

Inhibition of $O$-methyltransferase by sinefungin

Synthesis of $M F$ by locust farnesoic acid. SAdenosyl-methionine methyltransferase (OMT) prepared from CA was linear with time for at least $45 \mathrm{~min}$, increased with temperature and was dependent on substrate concentrations (FA and AdoMet) (Fig. 3). The enzyme manifested classical Michaelis-Menten kinetics. It had an apparent $K_{m}$ for AdoMet of $1.2 \times 10^{-6} \mathrm{M}$ and a $V_{\max }$ of $14.3 \times 10^{-9} \mathrm{M} / \mathrm{min}\left(K_{m}\right.$ for FA $\left.29 \mu \mathrm{M}\right)$. Sinefungin strongly inhibited the incorporation of radioactivity from [methyl- ${ }^{14} \mathrm{C}$ ]AdoMet into MF (labelled MF was
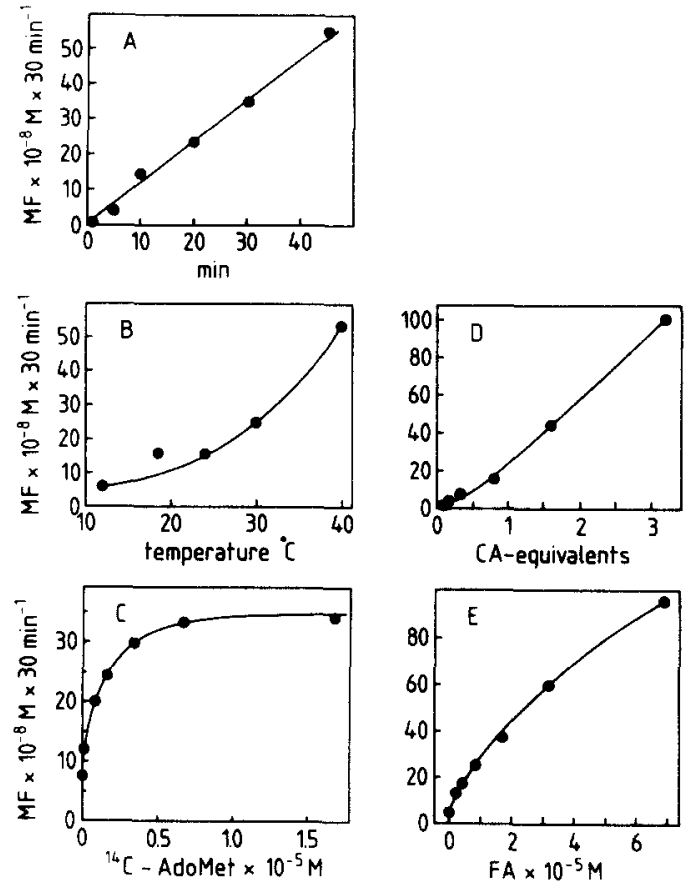

Fig. 3. Properties of OMT partially purified from locust CA. (A) Time course of MF synthesis; (B) temperature dependence of OMT activity; effects of various amounts of $\left[{ }^{14} \mathrm{C}\right]$ AdoMet $(\mathrm{C})$, of enzyme-containing extract (D) and of farnesoic acid (E) on enzyme activity. Each determination was done in duplicate.

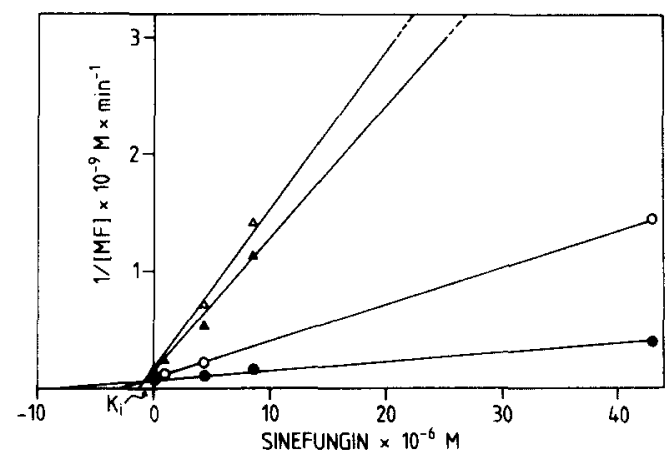

Fig. 4. Inhibition of locust OMT in the presence of various concentrations of sinefungin: $O, 0 ; 0,0.85 \mu \mathrm{M} ; \Delta$, $4.25 \mu \mathrm{M} ; \Delta, 8.50 \mu \mathrm{M}$. Each determination was done in duplicate. The data are plotted according to Dixon (1953). The inhibitor constant $\left(K_{i}\right)$ was determined directly from the graph.

Table 1. Effects* of sinefungin on sexual maturation during the first gonotrophic cycle

\begin{tabular}{cccccc}
\multicolumn{7}{c}{ of Locusta migratoria } \\
\hline $\begin{array}{c}\text { Sinefungin } \\
\text { injectedt } \\
(\mu \mathrm{g})\end{array}$ & $\begin{array}{c}\text { Haemolymph } \\
\text { protein } \\
(\mathrm{mg} / \mathrm{ml})\end{array}$ & $\begin{array}{c}\text { Ovary wt } \\
(\mathrm{mg})\end{array}$ & $\begin{array}{c}\text { Oocyte length } \\
(\mathrm{mm})\end{array}$ & $\begin{array}{c}\text { Mortality } \\
(\%)\end{array}$ & $N$ \\
\hline 0 & $67.7 \pm 3.9$ & $233.3 \pm 33.3$ & $4.3 \pm 0.6$ & 14 & 12 \\
6 & $67.2 \pm 5.2$ & $211.8 \pm 34.0$ & $3.9 \pm 0.3$ & 7 & 14 \\
60 & $59.3 \pm 3.9$ & $100.9 \pm 22.8$ & $2.6 \pm 0.4$ & 13 & 13 \\
150 & $36.9 \pm 2.3$ & $15.6 \pm 1.9$ & $<1.3$ & 9 & 10 \\
300 & $24.3 \pm 4.5$ & $8.3 \pm 1.8$ & $<1.3$ & 75 & 4 \\
\hline
\end{tabular}

* All determinations were made on day 15 after adult emergence. Data are mean values \pm SEM

†The amounts are the sum of six equal doses applied by repeated injections every second day. 
identified by HPLC; data not shown). When $\left[{ }^{14} \mathrm{C}\right]$ AdoMet was the variable substrate for locust OMT, sinefungin exhibited competitive inhibitory kinetics with a $K_{i}$ of $0.5-1.0 \times 10^{-6} \mathrm{M}$ (Fig. 4).

\section{DISCUSSION}

The biosynthesis of juvenile hormone occurs in Locusta migratoria by the AdoMet dependent methylation of FA to give MF which then is oxidized at the terminal double bond to (10R)2E,6-E-3,7-dimethyldodecadienoate methyl ester (epoxyfarnesoic acid methyl ester, JH III) (Hamnett et al., 1981; Feyereisen et al., 1981; Weirich, 1985). The results presented in this paper show that the enzyme farnesoic acid O-methyltransferase (OMT) was inhibited by sinefungin in a cell-free enzyme preparation from locust CA. The incorporation of [methyl- ${ }^{14} \mathrm{C}$ ]SAM into FA in the presence of sinefungin decreased drastically with increasing concentrations of the inhibitor. Although the enzyme was not completely purified some of its properties could be determined in a crude extract of the CA. For conversion of AdoMet and FA apparent $K_{m}$ values of 1.2 and $29 \mu \mathrm{M}$, respectively, were found. Kinetics of inhibition showed that sinefungin acts as competitive inhibitor with a $K_{i}$ of $0.5-1.0 \mu \mathrm{M}$. This inhibition constant is comparable to those found with a number of methyltransferases inhibited by sinefungin (e.g. Borchardt et al., 1979; Smith and Norton, 1980; Robert-Gero, 1980; O'Dea et al., 1982). The inhibition of JH synthesis in cultured locust CA may be due to several effects, including disturbance of regulatory processes in enzyme synthesis and transportation phenomena. The observations on OMT in the cell-free system suggest, however, that sinefungin may also act in organ culture to inhibit the same enzyme. The irreversibility in the short-term assay may in part be attributed to the greater affinity of sinefungin for OMT than AdoMet. Many of the in vivo effects are similar to those observed after allatectomy at early stages of sexual maturation (Chen et al., 1976; Lazarovici and Pener, 1977; Goltzene and Porte, 1978). The low haemolymph protein concentration may be in part caused by a lack of vitellogenin synthesis which is regulated by $\mathrm{JH}$ (Chen et al., 1976; Ferenz and Kaufner, 1981). It was, however, not possible to revert these effects by topical application of the $\mathbf{J H}$ analog (RS)-methoprene. Though the animals were not lethally affected by small doses of sinefungin, it may be expected that at least larval development and fertility of adult females will be severely impaired. Most likely, sinefungin acts in locusts as a generally toxic agent and the inhibition of $\mathrm{JH}$ biosynthesis may be only one of the reasons for the inhibition of ovarian development. Sinefungin may prove of importance in further development of a new class of insect growth regulators.

Acknowledgements - The support and advice by Dr D. Berg (Bayer, Leverkusen) is gratefully acknowledged. We thank Mrs E. P. Fischer for her excellent technical assistance. This work was supported by grants from the Deutsche Forschungsgemeinschaft to both of us and by a Heisenberg Fellowship to M.G.P.

\section{REFERENCES}

Borchardt R. T., Eiden L. E., Wu B. and Rutledge C. O. (1979) Sinefungin, a potent inhibitor of Sadenosylmethionine: protein O-methyltransferase. Biochem. biophys. Res. Commun. 89, 919-924.

Chen T. T., Couble P., DeLucca F. L. and Wyatt G. R. (1976) Juvenile hormone control of vitellogenin synthesis in Locusta migratoria. In The Juvenile Hormone (Edited by Gilbert L. I.), pp. 505-529. Plenum Press, New York.

Dixon M. (1953) The determination of enzyme inhibitor constants. Biochem. J. 55, 170-171.

Ferenz H. J. and Diehl I. (1983) Stimulation of juvenile hormone biosynthesis in vitro by locust allatotropin. Z. Naturforsch. 38c, 856-858.

Ferenz H. J. and Kaufner I. (1981) Juvenile hormone synthesis in relation to oogenesis in Locusta migratoria. In Juvenile Hormone Biochemistry (Edited by Pratt G. E. and Brooks G. T.), pp. 135-145. Elsevier, Amsterdam.

Ferenz H. J., Peter M. G. and Berg D. (1986) Inhibition of farnesoic acid methyltransferase by sinefungin. Agric. biol. Chem. 50(4), 1003-1008.

Feyereisen R., Pratt G. E. and Hamnett A. F. (1981) Enzymic synthesis of juvenile hormone in locust corpora allata: evidence for a microsomal cytochrome P.450 linked methyl farnesoate epoxidase. Eur. J. Biochem. 118, 231-238.

Feyereisen R. and Tobe S. S. (1981) A rapid partition assay for routine analysis of juvenile hormone release by insect corpora allata. Analyt. Biochem. 111, 372-375.

Goltzene F. and Porte A. (1978) Endocrine control by neurosecretory cells of pars intercerebralis and the corpora allata during the earlier phases of vitellogenesis in Locusta migratoria. Gen. comp. Endocr. 35, 35-45.

Hamill R. L. and Hoehn M. M. (1973) A new adeninecontaining antifungal antibiotic. II. Biological activity. J. Antibiot. 26, 463-465.

Hamnett A. F., Pratt G. E., Stott K. M. and Jennings R. C. (1981) The use of radio HRLC in the identification of the natural substrate of the $\mathbf{0}$-methyltransferase and substrate utilization by the enzyme. In Juvenile Hormone Biochemistry (Edited by Pratt G. E. and Brooks G. T.), pp. 93-105. Elsevier, Amsterdam.

Lazarovici P. and Pener M. P. (1977) Juvenile hormones and completion of oocyte development in the African migratory locust: a comparative study. Gen. comp. Endocr. 33, 434-452.

Lowry O. H., Rosenbrough N. J., Parr A. L. and Randall R. J. (1951) Protein measurement with the Folin phenol reagent. J. biol. Chem. 193, 264-275.

Mordue W. and Goldsworthy G. L. (1969) The physiological effects of corpus cardiacum extracts in locusts. Gen. comp. Endocr. 12, 360-369.

O'Dea R. F., Pons G., Hansen J. A. and Mirkin M. L. (1982) Characterization of protein carboxyl-O methyltransferase in the spontaneous in vivo murine C1300 neuroblastoma. Cancer Res. 42, 4433-4436.

Peter M. G., Gunawan S. and Emmerich H. (1979) Preparation of optically pure juvenile hormone I labelled in the ester methyl group with tritium at very high specific activity. Experientia 35, 1141-1142.

Reibstein D. and Law J. H. (1973) Enzymatic synthesis of insect juvenile hormones. Biochem. biophys. Res. Commun. 55, 266-272.

Robert-Gero M., Pierre A., Vedel M., Enoug J., Lawrence F., Raies A. and Lederer E. (1980) Analogues of Sadenosylhomocysteine as in vitro inhibitors of transmethylases and in vivo inhibitors of viral oncogenesis and other cellular events. In Enzyme Inhibitors (Edited by Brodbeck U.), pp. 61-74. Verlag Chemie, Weinheim.

Smith D. D. and Norton S. J. (1980) Inhibition of cyclopropane fatty acid synthetase by sinefungin and $A$ 9145C. Biochem. biophys. Res. Commun. 94, 1458-1462. 
Weirich G. F. (1985) Epoxyfarnesoic acid methyltransferase. Meths Enzym. 111, 540-544.

Weirich G. R. and Culver M. G. (1979) SAdenosylmethionine: juvenile hormone acid methyl- transferase in male accessory reproductive glands of

Hyalophora cecropia (L.). Archs Biochem. Biophys. 198, 175-181. 